\title{
PROBLEMATIC ASPECTS OF STATE POLICY MODERNIZATION IN THE CONDITIONS OF DIGITALIZATION
}

\section{Alina L. Pomaza-Ponomarenko}

Head of the Department, Scientific Department on Problems of State Security of Scientist, Training Research and Production Centre, National University of Civil Defence of Ukraine,

Kharkiv, Ukraine

\section{Larysa M. Hren}

Associate Professor, Department of Pedagogy and Psychology of Management of Social Systems acad. I. A. Zyazyuna, National Technical University "Kharkiv Polytechnic Institute",

Kharkiv, Ukraine

\section{Olena L. Durman}

Assistant Professor, Department of Public Administration and Local Government, Kherson National Technical University, Kherson, Ukraine

\section{Nataliia V. Bondarchuk}

Professor, Department of Accounting, Taxation and Financial - Security Management, Dnipro State Agrarian and Economic University, Dnipro, Ukraine

\section{Eugenia V. Vozniuk}

Associate Professor, International Relations and Regional Studies Department, Faculty of International Relations, Lesya Ukrainka Eastern European National University,

Lutsk, Ukraine

\begin{abstract}
The economy of a country that uses digitalization processes can be called successful and efficient, forasmuch as it saves time and simplifies the procedures for applying to government bodies. The state policy that was applied during the digitalization process included a wide range of different indicators, and it was taken into account during the country's transition to digitalization processes. It has been analyzed that the development of informatization processes, the emergence of industries using innovative products and technologies have led to striking changes that are contributing to shaping the current state of the economy, as well as modernizing state policy in the conditions
\end{abstract}


Alina L. Pomaza-Ponomarenko, Larysa M. Hren, Olena L. Durman, Nataliia V. Bondarchuk and Eugenia V. Vozniuk

of digitalization. It has been revealed that currently the governments of the leading countries of the world are already making significant efforts to unify state management processes to the maximum in order to avoid inappropriate costs for improving the functions of outdated systems. It has been proved that the implementation of systems, digitalization of the economy, access to administrative resources online - all this should indicate accessibility and simplification, however, in Ukraine and in other countries of the world there are certain problems with access to the Internet. Such indicators, as: world internet usage and population statistics 2020 year-q1 estimates, internet world Penetration Rates by Geographic Regions - 2020 Q1 (\%) have been analyzed; the dynamics of the indicator of communication subscribers' amount as of January 1, 2018 - January 1, 2019 (thousands of persons) has been tracked. The problematic aspects of state policy modernization in the conditions of digitalization have been highlighted and ways to solve them have been proposed.

Keywords: State Policy, Digitalization process, Modernization, Digital divide, Digitalization

Cite this Article: Alina L. Pomaza-Ponomarenko, Larysa M. Hren, Olena L. Durman, Nataliia V. Bondarchuk and Eugenia V. Vozniuk, Problematic Aspects of State Policy Modernization in the Conditions of Digitalization, International Journal of Management, 11 (6), 2020, pp. 508-515.

http://iaeme.com/Home/issue/IJM?Volume=11\&Issue=6

\section{INTRODUCTION}

In modern conditions, especially during the formation of the information society and the development of the digital economy, which in turn have become key leverages of economic development, it is important to solve problematic issues in the process of state policy modernization. The basic key factors in the implementation of the policy modernization of national importance are the digitalization processes, which are as follows: the development of information technologies, intellectual potential, the development of intangible production. The above-mentioned factors are able to create favourable conditions for the effective development of economic systems, that is, during their use a new economic paradigm may be formed. If one considers the processes of digitalization in the context of public direction, then with the help of the latter it is possible to improve certain mechanisms related to state policy. The economy of a country that uses digitalization processes can be called successful and efficient because it saves a lot of time and simplifies the procedures for applying to public authorities. Despite the importance of these processes, certain disagreements still arise in the process of introducing the latest technologies into the work; that is, in other words, there are certain internal and external factors that can have both positive and negative effects on digitalization processes. Within this framework, an important role in the implementation of the economic process and the construction of the digital economy is played by targeted state policy and mechanisms created in accordance with it, as well as tools of public administration, through which this mechanism operates and can ensure effective formation and development of digitalization processes.

\section{LITERATURE REVIEW}

During the state regulation of economic processes in the conditions of digitalization of the economy of the world's leading countries, these processes were under way, taking into account the characteristics of the country. The state policy that was applied during the digitalization process included a wide range of different indicators; they were taken into account during the country's transition to digitalization processes. The basic ones are the following: market conjuncture, the state of infrastructure and production sector development, the country's vector 
for the application and introduction of innovative components into the country's economy, the influence of factors of endogenous and exogenous environment, etc.. The processes of informatization, the emergence of industries, using innovative products and technologies, have led to impressive changes that are involved in forming the current state of the economy, as well as the modernization of state policy in the conditions of digitalization.

In 2018, the Government of Ukraine approved the "Concept for the Development of the Digital Economy and Society of Ukraine for 2018-2020" and approved its main provisions. According to the document specified, its basic goal is to implement the "Digital Agenda Ukraine 2020", which will provide the removal of obstacles that will arise in the way of Ukraine in the process of digital transformation. According to the action plan for the implementation of the above-mentioned Concept, the corresponding emphasis is as follows:

- development of the basic priority areas in the digital economy;

- development of key digital skills and competences of citizens;

- provision of methodological, normative and organizational character;

- formation and development of digital infrastructures;

- creation and development of digital technologies' export;

- development of priority spheres of life in the digital dimension.

The issue concerning elimination of obstacles which can arise during digital transformation of Ukraine is considered as a basis in this Concept. These actions are aimed at attracting investment, integrating cooperation with EU, eliminating digital inequality. According to the basic provisions of the [1]:

- notes the basic milestones in the country's digital economy;

- forms the basic principles on which the state policy should be based in the process of digitalization;

- defines the basic priority objectives for three years;

- proposes and develops initiatives to create digital infrastructure and minimize "digital divide";

- offers incentives for the creation and development of industries with digital technologies' application;

- identifies and analyzes the digital skills of the society, as well as the level of education in this area;

- identifies important areas in critical condition that require the introduction and implementation of appropriate digital transformation projects on a national scale.

In addition, author in [2] claims that the digitalization of the economy affects all areas of public life, as well as educational processes. In other words, under current conditions, the modernization of the educational system is an important priority in modern education, that is, a system of coordination actions has been introduced aimed at the interaction of subjects of educational policy. In addition, it has been noted that an important goal of state educational policy should be implemented, namely: creation and formation of an innovative system of national character.

In particular, in study [3] was drawn attention to the processes of digitalization of public services and the introduction of e-government and e-health. In turn, the processes of modernization and digitalization of public services can increase the efficiency not only of state policy, public administration, but also business, citizens and the society as a whole. 
As the researchers in [4] assure, currently a large-scale introduction and use of "egovernment" is taking place in Ukraine; it determines the development of such important processes as: digitalization process and digitalization. These processes are under way during the development of the administrative process algorithm, which aims to improve the quality of service delivery, in particular due to the reduction of time for their implementation, as well as increased transparency in these processes. In addition, the country's citizens are also actively involved in the digitization process, as the latter assess the services provided by using electronic media.

It should be noted that an important aspect of the modernization of state policy is also ecommerce through which financial and trade transactions are carried out. Accordingly, in study [5] was noted that there are certain psychological aspects of e-commerce management's effectiveness, which remain insufficiently studied; there is a lack of theoretical substantiation and empirical data on the features and basic elements of interaction of e-commerce entities, the leading factors of its optimality.

In a study [6] it has been indicated that during the formation of "digital society" the basic functions of the state should be as follows: creation of optimal conditions and provision of opportunities for the implementation of digitalization processes in the national economy, as well as the development of digital technologies.

Researcher in his investigation [7] notes, that the digital divide is the main failure in the market for services during modernization in the conditions of digitalization. Herewith, currently there is a new criterion in the world, by which society is differentiated into social groups - it is the possession of information and knowledge.

The study [8] proves that in modern conditions of society's digitalization, the effective public administration should use digital technologies. When e-government is used in public administration, this leads to advantages in the modern information world.

\section{DATA AND METHODOLOGY}

Data from the State Statistics Service of Ukraine, Internet World Stats, have been used to study the basic indicators of economic activity. The following methods have been used, namely: method of comparative analysis of indicators world internet usage and population statistics 2020 year-q1 estimates; internet world Penetration Rates by Geographic Regions - 2020 Q1 (\%); the dynamics of the indicator of communication subscribers' amount as of January 1, 2018 - January 1, 2019 (thousands of persons); abstract-logical method - for analytical generalization and formulation of conclusions.

\section{RESULTS AND DISCUSSION}

As of today, the Government of Ukraine has made changes to a number of legal documents related to improving the digital position of the executive branch. The reformation of analog systems will be carried out by using these documents, for much as they are currently inefficient and disadvantageous, that is, they will be converted to digital format. As of today, the goal of digitization policy is to develop a common approach to providing access to administrative services. The governments of the leading countries of the world currently are making significant efforts to unify state management processes to the maximum in order to avoid inappropriate costs for improving the functions of outdated systems. Particular attention is paid to the centralization of state "digital" infrastructure.

It should be noted that the United Kingdom is the leading country in this area, forasmuch as it was in this country that the Ministry of Digital Economy was first established, which was considered as a state institution. The above-mentioned state used "cloud technologies" for the first time, which led to the creation of appropriate "Date Centers". The United Kingdom 
remains a leading country till present time in the use of innovative products and technologies. It was this country that determined the development of the methodology and implementation mechanisms of "digital economy" concept, forasmuch as it introduced this terminology into world science.

The main subject in the formation of the Eastern Partnership both in Ukraine and in the region within the framework of the digitalization of the economy is the National Commission for State Regulation in the Field of Communications and Informatization (NCCIR). In 2018, the NCCIR holds the presidency of the Eastern Partnership Electronic Communications Regulatory Network on behalf of Ukraine. According to the Joint Working Document "Eastern Partnership - 20 Expected Results by 2020", partner countries will have to develop strategies for the use of frequencies agreed between it and EU. However, such strategy is not being developed in Ukraine at the moment. At the same time, the Eastern Partnership Electronic Communications Regulatory Network has initiated a process to harmonize pricing and reduce roaming tariffs among partner countries. The basis for this process has been laid - the corresponding study provides a general overview of international roaming markets and the legislative framework in the countries of the Eastern Partnership, as well as recommendations for the implementation of a harmonized approach. Despite the extensive discussions, Ukraine has not taken significant steps to develop a national strategy for the development of broadband service access (hereinafter - BSA) to the Internet. Such a document, in fact, should be the starting point in the development of the necessary infrastructure for the harmonization of digital markets. In contrast, we have got a positive experience in the use of "digital" technologies, for example in the field of public procurement, in particular, the use of the Prozorro program.

Moreover, in 2019, the National Civil Service Agency for the first time applied a new information system that manages human resources, that is PoClick. In 2020, the system should be used by all ministries, and in the future by all state bodies of Ukraine. The present system works on the principle of transparency, that is, prior to PoClick, basic information about the civil servant is entered, that is, his task, responsibilities, salary. The launch of such system makes it possible to speed up the process of digitization, and also determines the transparency and openness of people working in the civil service. Implementation of systems, digitalization of the economy, access to online administrative resources - all this should indicate accessibility and simplification, however, in Ukraine and in other countries there are some problems with Internet access.

For instance, there is a fairly high average and an even distribution of broadband Internet access in our country. At the same time there is a gap between urban and rural areas in Ukraine: about $30 \%$, and among the rural population (up to 35\%) do not have broadband Internet access. It is worth noting that this is not the only problem of a particular region or a country, however, this trend is inherent in the whole world, and, hence, every person (Table 1).

Table 1 World internet usage and population statistics 2020 year-q1 estimates [9]

\begin{tabular}{|c|c|c|c|c|c|c|}
\hline $\begin{array}{c}\text { World } \\
\text { Regions }\end{array}$ & $\begin{array}{c}\text { Population } \\
\text { (2020 Est.) }\end{array}$ & $\begin{array}{c}\text { Population\% } \\
\text { of World }\end{array}$ & $\begin{array}{c}\text { Internet } \\
\text { Users 31 } \\
\text { May 2020 }\end{array}$ & $\begin{array}{c}\text { Penetration } \\
\text { Rate (\% } \\
\text { Pop.) }\end{array}$ & $\begin{array}{c}\text { Growth } \\
\mathbf{2 0 0 0 -} \\
\mathbf{2 0 2 0}\end{array}$ & $\begin{array}{c}\text { Internet } \\
\text { World } \\
\text { \% }\end{array}$ \\
\hline Africa & $1,340,598,447$ & $17.2 \%$ & $526,710,313$ & $39.3 \%$ & $11,567 \%$ & $11.3 \%$ \\
\hline Asia & $4,294,516,659$ & $55.1 \%$ & $2,366,213,308$ & $55.1 \%$ & $1,970 \%$ & $50.9 \%$ \\
\hline Europe & $834,995,197$ & $10.7 \%$ & $727,848,547$ & $87.2 \%$ & $592 \%$ & $15.7 \%$ \\
\hline $\begin{array}{c}\text { Latin } \\
\text { America / } \\
\text { Caribbean }\end{array}$ & $658,345,826$ & $8.5 \%$ & $453,702,292$ & $68.9 \%$ & $2,411 \%$ & $10.0 \%$ \\
\hline Middle East & $260,991,690$ & $3.3 \%$ & $183,212,099$ & $70.2 \%$ & $5,477 \%$ & $3.9 \%$ \\
\hline
\end{tabular}


Alina L. Pomaza-Ponomarenko, Larysa M. Hren, Olena L. Durman, Nataliia V. Bondarchuk and Eugenia V. Vozniuk

\begin{tabular}{|c|c|c|c|c|c|c|}
\hline $\begin{array}{c}\text { World } \\
\text { Regions }\end{array}$ & $\begin{array}{c}\text { Population } \\
\text { (2020 Est.) }\end{array}$ & $\begin{array}{c}\text { Population\% } \\
\text { of World }\end{array}$ & $\begin{array}{c}\text { Internet } \\
\text { Users 31 } \\
\text { May 2020 }\end{array}$ & $\begin{array}{c}\text { Penetration } \\
\text { Rate (\% } \\
\text { Pop.) }\end{array}$ & $\begin{array}{c}\text { Growth } \\
\mathbf{2 0 0 0 -} \\
\mathbf{2 0 2 0}\end{array}$ & $\begin{array}{c}\text { Internet } \\
\text { World } \\
\text { \% }\end{array}$ \\
\hline $\begin{array}{c}\text { North } \\
\text { America }\end{array}$ & $368,869,647$ & $4.7 \%$ & $348,908,868$ & $94.6 \%$ & $223 \%$ & $7.5 \%$ \\
\hline $\begin{array}{c}\text { Oceania / } \\
\text { Australia }\end{array}$ & $42,690,838$ & $0.5 \%$ & $28,917,600$ & $67.7 \%$ & $279 \%$ & $0.6 \%$ \\
\hline $\begin{array}{c}\text { WORLD } \\
\text { TOTAL }\end{array}$ & $7,796,949,710$ & $100.0 \%$ & $4,648,228,067$ & $59.6 \%$ & $1,187 \%$ & $100.0 \%$ \\
\hline
\end{tabular}

From the indicators analyzed above, it can be noted that according to the indicator Internet Users as of May 31, 2020 the largest value is observed in Asia, it can be explained there that there is the highest population that would be able to access the Internet. In addition, such leading countries of the world as Japan, Kazakhstan, China, North and South Korea are located in Asia. In terms of Internet World\% indicator, the countries of Asia, then Europe and Africa are also occupying leading positions. It is also worth considering such an important indicator as the Internet world Penetration Rates by Geographic Regions - 2020 Q1 (\%) (Figure1).

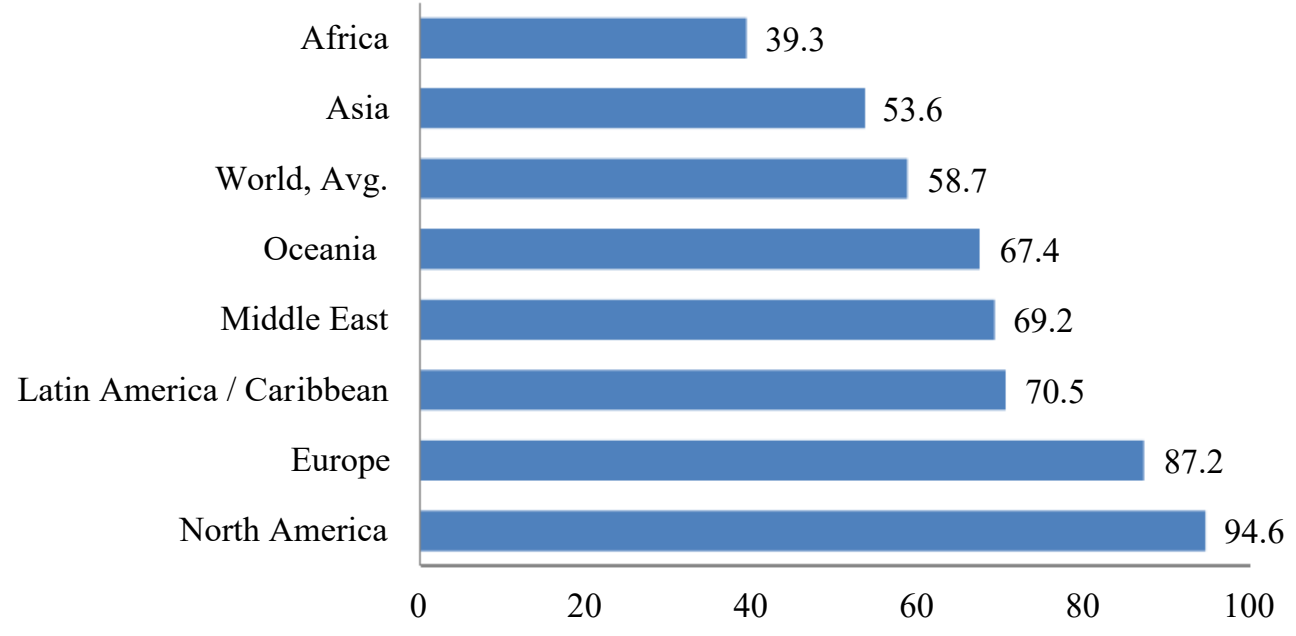

Figure 1 Internet world Penetration Rates by Geographic Regions - 2020 Q1 (\%) [9]

From the above figure, it can be seen that according to the indicator Internet world Penetration Rates by Geographic Regions - 2020 Q1 the highest access to the Internet is observed in North America - 94,6\%, Europe - 87,2\%, Latin America / Caribbean - 70, 5\%, the lowest access is observed in countries of Africa. It should be noted that in Ukraine, as of January 1, 2019, 25312,7 thousand people (Table 2) have broadband Internet access.

Table 2 Number of communication subscribers as of January 1, 2018 - January 1, 2019 (thousands of persons) [10]

\begin{tabular}{|c|c|c|c|c|}
\hline \multirow{2}{*}{ Indicators } & \multicolumn{2}{|c|}{ Total } & \multicolumn{2}{c|}{ Including home } \\
\cline { 2 - 5 } & 2018 & 2019 & 2018 & 2019 \\
\hline $\begin{array}{c}\text { Number of Internet subscribers } \\
\text { of which with the provision of broadband } \\
\text { access }\end{array}$ & 23632,3 & 26066,8 & 21275,8 & 23354,2 \\
\hline $\begin{array}{c}\text { including } \\
\text { fixed }\end{array}$ & 22625,8 & 25312,7 & 20442,8 & 22861,1 \\
\hline wireless & 5116,8 & 5288,3 & 4762,9 & 4936,2 \\
\hline & 17509,0 & 20024,4 & 15679,9 & 17924,9 \\
\hline
\end{tabular}


The conducted analysis shows that the number of Internet subscribers who use the latter at home is about $89,56 \%$ in 2019 . With the provision of broadband wireless Internet access there are by 14736,1 thousand people more than fixed in 2019. Compared to 2018, the number of Internet subscribers increased by 2434,5 thousand people in 2019.

According to [11], the level of digitalization directly affects sustainable development, financial and economic development of states. Digitalization affects business and general economic activity [11].

In addition, as of today, in Ukraine, the basic digitization technologies that are currently used include: multi-vector involvement and awareness of citizens; possibility of open data; electronic identification of citizens; analytics; use of "smart" machines and tools; "Internet of Things"; "Digital" platforms, applied in state policy, in other words, in public administration.

If we consider the "Internet of Things" as an example, the following is predicted:

- 64 billion IoT devices are expected by 2025.

- By the end of 2020, approximately 5,8 billion car and corporate gadgets will be connected to the Internet of Things.

- By 2022, 100\% of the world's population will have LPWAN covering (a network with low power consumption and bandwidth for detectors and sensors).

- By 2025, the Internet of Things market will amount from 4 to 11 trillion USD.

- The most important driver of IoT solutions implementation for 54\% of enterprises is saving money in the future. In $23 \%$ of cases, the goal centers around increasing competitiveness.

- The portable devices market will grow to 1,1 billion USD by 2022 .

- For $97 \%$ of companies, the processing of data received from the Internet of Things is a problem.

- The market for banking services and financial institutions using IoT solutions will grow to 2,03 billion USD by 2023 .

It is worth agreeing with researchers that the use of digital technology and innovation in the public sector is rather important, as well as improving the existing public administration system, however, modernization of state policy in the conditions of digitalization should be carried out carefully, as there are many problems and risks of imperfect use of certain information systems.

\section{CONCLUSION}

At the present stage of state policy modernization in the conditions of digitalization, there is a problem of the imperfection of legal support for issues that are aimed at resolving objectives of a digital economy's development. The solution of this issue should be carried out by presenting of digitalization process in state programs, especially those related to the provision of public services, entrepreneurship, health care; that is, it is necessary to create appropriate information and analytical system, which would deal with ensuring and addressing issues of accessibility and transparency. In addition, the problematic aspects related to the modernization of state policy in the conditions of digitalization include: inefficiency of the mechanism of state management of integration processes during the digitalization of the economy, imperfect tax base, lack of an effective concept that would be designed for the development of economic sectors, insufficient state support for the introduction of digital technologies, lack of development in the field of digital infrastructure, threat to property, life, personal and national security in general (if a hacker attack or unauthorized access to data is carried out). The solution to these issues should be carried out at the expense of: improving the regulatory framework in the field of digitalization, improving the mechanism of integration processes, establishing tax 
Alina L. Pomaza-Ponomarenko, Larysa M. Hren, Olena L. Durman, Nataliia V. Bondarchuk and Eugenia V. Vozniuk

incentives and tax rates for IT industry, state support for the introduction of digital technologies, improvement of digital infrastructure, prevention of unauthorized access to data.

\section{REFERENCES}

[1] The concept of development of the digital economy and society of Ukraine. Legislation of Ukraine, 2019. http://zakon.rada.gov.ua/laws/show/67-2018-\%D1\%80

[2] Ajazha, M. State reform of higher education modern conditions. Abstracts Collection. Zaporizhzhia National University, 2019, pp. 7-10.

[3] Klenin, O. V. Main trends of digital transformation of the state and business. Materials of the XVIII International Scientific and Practical Conference: Building an information society: resources and technologies. Kyiv, 2019, pp. 44-47.

[4] Mamonova, V. V. and Kalmykov, E. V. Actualization of the introduction of electronic communication interactions in the system of public administration. Problems of development of public administration in Ukraine. Lviv, 2019, pp. 196-199.

[5] Akimov, O., Karpa, M., Parkhomenko-Kutsevil, O., Kupriichuk, V. and Omarov, A. Entrepreneurship education of the formation of the e-commerce managers professional qualities. Journal of Entrepreneurship Education, 23(S1), 2020.

[6] Oleshko, A. A. Key imperatives of public management of digital development. State and regions. Public Administration, 3(67), 2019, pp. 87-91.

[7] Krynytsia, S. O. State policy for digitalization of Ukraine's economy. Financial space, 3(31), 2018, pp. 50-57.

[8] Lopushinsky, I. P. "Digitalization" as the basis of public administration by road transformation and reform of ukrainian society. Theory and practice of public administration and local selfgovernment, 2, 2018. http://el-zbirn-du.at.ua/2018_2/20.pdf

[9] World Internet Usage Statistics News and World Population Stats. Internet World Stats, 2017. https://www.internetworldstats.com/stats.htm

[10] Number of communication subscribers on January 1, 2018 - January 1, 2019 (thousands, persons). State Statistics Committee of Ukraine, 2019. http://www.ukrstat.gov.ua/operativ/operativ2019/zv/az/az_u/az0119_u.htm

[11] Bashtannyk, V., Buryk, Z., Kokhan, M., Vlasenko, T. and Skryl, V. Financial, economic and sustainable development of states within the conditions of industry 4.0. International Journal of Management, 11(4), 2020, pp. 406-413.

[12] Mamaev O. A., Panov S. A., Shepelev V. V., Concept of Modernization of Socio-Economic Programs in the Region, International Journal of Mechanical Engineering and Technology 9(13), 2018, pp. 1482-1488.

[13] Arseniy Aleksandrovich Lebedev, Modernization of Marketing Conditions in the Implementation of Remote Education Programs, International Journal of Civil Engineering and Technology, 10(01), 2019, pp. 1612-1630 